\title{
Analysis of the EGFR gene mutation in patients with non- small cell lung cancer in a Chinese population
}

\author{
Ju-yi Li ${ }^{1}$, Ying Liu ${ }^{2}$ and Ai-ping Deng ${ }^{1 *}$ \\ ${ }^{1}$ Department of Pharmacy, The Central Hospital of Wuhan, Wuhan, ${ }^{2}$ Department of Pharmacy, The Central Hospital of \\ Huangshi, Huangshi, Hubei Province, 430021, China \\ *For correspondence: Email: wxfls0@163.com
}

\begin{abstract}
Purpose: To investigate the epidermal growth factor receptor (EGFR) gene mutations and analyze their clinical significance in patients with non-small cell lung cancer (NSCLC) in Hubei province of China. Methods: A total of 138 paraffin embedded tissues were taken from patients with NSCLC who were treated at Hubei Hospital from January 2014 to June 2015. The tissue DNA was extracted and EGFR mutation was evaluated by polymerase chain reaction (PCR) sequencing analysis of exons 18, 19, 20, and 21.

Results: The overall mutation rate of EGFR gene was $30.43 \%(42 / 138)$ in 138 NSCLC patients. The mutation rates of EGFR gene at exon 18, 19, 20, 21 were $0 \%$ (0/138), $13.8 \%$ (19/138), $0.7 \%(1 / 138)$ and $15.9 \%(22 / 138)$, respectively. The mutation rate of EGFR gene was higher in female patients than that in males $(62.2 \%(28 / 45)$ vs $15.1 \%(14 / 93), p<0.01)$, and higher in non-smoking patients than in smoking ones $(p<0.05)$, but had no correlation with age in NSCLC patients $(p>0.05)$. EGFR mutation frequency in adenocarcinoma was higher than that in squamous cell carcinoma: $33.9 \%$ (41/121) vs. 5.9 $\%(1 / 17, p<0.05)$.

Conclusion: EGFR mutations in NSCLC patients mainly exist in exons 19 and 21, and the mutation rate of exon 21 is higher than that of exon 19, which is more commonly found in female, adenocarcinoma and non-smoking patients.
\end{abstract}

Keywords: Non-small cell lung cancer, Epidermal growth factor receptor (EGFR), Targeted therapy, Sequencing

Tropical Journal of Pharmaceutical Research is indexed by Science Citation Index (SciSearch), Scopus, International Pharmaceutical Abstract, Chemical Abstracts, Embase, Index Copernicus, EBSCO, African Index Medicus, JournalSeek, Journal Citation Reports/Science Edition, Directory of Open Access Journals (DOAJ), African Journal Online, Bioline International, Open-J-Gate and Pharmacy Abstracts

\section{INTRODUCTION}

Lung cancer is one of the most common cancers in the world and is responsible for one third of all cancer-related death [1], NSCLC comprising 80 $\%$ of lung cancers is now a disease that can be classified into clinically relevant molecular subgroups, each with distinct clinicopathologic features and potential for targeted therapies [2]. Among these molecular subsets, the identification of EGFR tyrosine kinase domain mutations that predict sensitivity to tyrosine kinase inhibitors (TKIs) is the most prominent event [3-5]. Patients with EGFR mutations, however, are also a heterogeneous group with different sensitivity to TKIs, such as erlotinib or gefitinib. EGFR kinase domain mutations occur primarily in exons 18-21 which encode part of the tyrosine kinase domain [6-8].

The presence of EGFR mutations has also been associated with treatment in East Asian countries, female sex, bronchioloalveolar carcinoma subtype of adenocarcinoma, and 
improved survival [9]. One factor with a very strong association with these sensitivity mutations was a history of never smoking cigarettes [10]. Patients with a high likelihood of response to treatment with tyrosine kinase inhibitors can be identified by molecular analysis of lung tumor tissue to detect these sensitivity mutations. The personalization of cancer care aims to predict effective therapy regimes according to the molecular profiles of individual patients and their cancers and only patients who carried EGFR mutation can benefit from targeted therapies $[4,11]$.

In this study, we performed multiplex amplification of exons 18-21 of EGFR using pyrosequencing to detect base changes or deletions in codons $746-753$ to analyze the mutational frequency in 138 cases of lung cancer and provide theoretical basis for individualized diagnosis and treatment of lung cancer patients of Hubei province in China.

\section{METHODS}

\section{Tissue procurement}

Tumor specimens were collected from 138 patients with NSCLC at the time of surgical resection before systemic treatment. All specimens were frozen immediately and stored in liquid nitrogen until DNA was extracted. Demographic characteristics and clinical data, including age, sex, smoking status, date of diagnosis, tumor stage, treatment, progression were obtained. Our institutional review board approved this study, and written informed consent was obtained from all patients. This study was approved by the Ethics Committee of the Hubei Hospital (approval ref. no. 20140101) and followed the guidelines of Helsinki Declaration [12].

\section{DNA extraction, PCR and direct sequencing of EGFR gene}

DNA of the tumor tissue was successfully extracted by TIANamp Blood/cell/tissue genomic DNA extraction kit (Tiangen, Beijing, China) according to the manufacturer's instruction. Four separate PCR reactions, each with the corresponding pair of primers, were used to amplify exons $18-21$ of the EGFR genes. The designed primers were as follows. Exon 18: Forward: 5'-CAA GTG CCG TGT CCT GG-3'; Reverse: 5'-AAA TGC CTT TGG TCT GTG AA3', Exon 19: Forward: 5'-ATA TCA GCC TTA GGT GCG G-3', Reverse: 5'-GGG AAA GAC ATA GAA AGT GAA CA-3', Exon 20: Forward: 5'-TTC ACA GCC CTG CGT AAA C-3', Reverse: 5'-TTG AAT CCA AAA TAA AGG AAT GT-3'; Exon 21: Forward: 5'-TGG TCA GCA GCG GGT TAC-3', Reverse: 5'-TCA TTC ACT GTC CCA GCA AG-3'. PCR amplification was carried out on ABI 9700 PCR thermal cycler (Applied Biosystems, USA). The PCR amplification was performed with a denaturation step at $94^{\circ} \mathrm{C}$ for 2 min, followed by 35 cycles of $94{ }^{\circ} \mathrm{C}$ for $20 \mathrm{~s}, 52$ ${ }^{\circ} \mathrm{C}$ for $10 \mathrm{~s}, 72{ }^{\circ} \mathrm{C}$ for $30 \mathrm{~s}$, and final extension step at $72{ }^{\circ} \mathrm{C}$ for $2 \mathrm{~min}$. The PCR products were analyzed using a PyroMark Q24 system (Qiagen) according to standard protocols. The order of nucleotide dispensation was chosen based on suggestions provided by the PyroMark Assay Design Software 2.0.

\section{Statistical analysis}

The association between two categorical variables was assessed using the Chi-square test. Allele frequency was determined via direct counting and a $p$-value less than 0.05 denoted the presence of a statistically significant difference.

\section{RESULTS}

\section{Patient characteristics}

There were 93 men and 45 women. Sixty six patients declared their smoking history. The clinical and demographic characteristics of the 138 NSCLC patients are shown in Table 1.

Table 1: The clinical and demographic characteristics of NSCLC patients

\begin{tabular}{|c|c|c|c|c|}
\hline Variable & General data & & Cases (N) & Percentage (\%) \\
\hline \multirow{2}{*}{ Gender } & Male & & 93 & $67.4(93 / 138)$ \\
\hline & Female & & 45 & $32.6(45 / 138)$ \\
\hline \multirow{2}{*}{ Age } & $\leq 60$ years & & 103 & $74.6(103 / 138)$ \\
\hline & $>60$ years & & 35 & $25.4(35 / 138)$ \\
\hline \multirow{3}{*}{ Smoking or not } & Smoking & $\begin{array}{c}\text { Male } \\
\text { Female }\end{array}$ & $\begin{array}{c}61 \\
5\end{array}$ & $\begin{array}{c}44.2(61 / 138) \\
3.6(5 / 138)\end{array}$ \\
\hline & & Male & 32 & $23.2(32 / 138)$ \\
\hline & Non-Smoking & Female & 40 & $29.0(40 / 138)$ \\
\hline
\end{tabular}


Distribution of EGFR mutations in 138 NSCLC patients

The overall mutation rate in EGFR was $30.43 \%$ $(42 / 138)$. With respect to the EGFR mutation status, we found 19 patients $(13.8 \%)$ with an inframe deletion in exon 19, 21 patients (15.2\%) with L858R mutations and 1 patient $(0.7 \%)$ with L861Q mutation in exon 21 and 1 patient $(0.7 \%)$ with T790M mutation in exon 20 in the 138 NSCLC patients, as shown in Table 2.

Association between EGFR mutation and clinical characteristics in 138 NSCLC patients

As shown in Table 3, the mutation rate of EGFR gene had no correlation with age in NSCLC patients $(30.1 \%$ vs $31.4 \%, p>0.05)$, it was higher in female patients than that in males (62.2 $\%(28 / 45)$ vs $15.1 \%$ (14/93), $p<0.01)$, and higher in non-smoking patients than in smoking ones $(28.1 \%$ vs $8.2 \%$ in males, $71.8 \%$ vs 16.7 $\%$ in females, $p<0.05)$. EGFR mutation frequency in adenocarcinoma was higher than that in squamous cell carcinoma ( $33.9 \%$ vs 5.9 $\%, p<0.05)$.

As shown in Table 4, in both adenocarcinoma and squamous cell carcinoma, the mutation rate of EGFR gene was higher in female patients than that in males ( $65.8 \%$ vs $15.7 \%, 14.3 \%$ vs $0 \%$ ).

\section{DISCUSSION}

Gefitinib and erlotinib are orally available EGFRTKIs frequently used to treat NSCLC patients with EGFR mutations $[13,14]$. EGFR proteins control essential signaling pathways that regulate cell proliferation [15]. Increased levels of EGFR gene expression are observed in NSCLC, and its expression is correlated with an adverse prognosis [16].

Table 2: Mutations status in exons 18 - 21 of EGFR in 138 NSCLC patients

\begin{tabular}{lccc}
\hline Exon & Mutations type & Mutation cases & Mutation rate (\%) \\
\hline 18 & G719S & 0 & $0(0 / 41)$ \\
19 & Del E746-A750 & 19 & $13.8(19 / 41)$ \\
20 & T790M & 1 & $0.7(1 / 41)$ \\
21 & L861Q & 1 & $0.7(1 / 41)$ \\
Total & L858R & 21 & $15.2(21 / 41)$ \\
\hline
\end{tabular}

Table 3: Association between EGFR mutation and clinical characteristics in 138 NSCLC patients

\begin{tabular}{|c|c|c|c|c|c|c|}
\hline \multirow{2}{*}{\multicolumn{2}{|c|}{ Clinical characteristics }} & \multirow{2}{*}{$\begin{array}{l}\text { Detected } \\
\text { cases }\end{array}$} & \multicolumn{2}{|c|}{ EGFR } & \multirow{2}{*}{$\begin{array}{c}\text { Mutation rate } \\
(\%)\end{array}$} & \multirow{2}{*}{$P$-value } \\
\hline & & & Mutation & $\begin{array}{c}\text { No } \\
\text { mutation }\end{array}$ & & \\
\hline \multicolumn{7}{|c|}{ Age } \\
\hline \multirow{2}{*}{\multicolumn{2}{|c|}{$\begin{array}{l}\leq 60 \text { years } \\
>60 \text { vears }\end{array}$}} & 103 & 31 & 72 & 30.1 & \multirow{2}{*}{0.882} \\
\hline & & 35 & 11 & 24 & 31.4 & \\
\hline \multicolumn{7}{|c|}{ Gender } \\
\hline Male & & 93 & 14 & 79 & 15.1 & \multirow{2}{*}{0.000} \\
\hline Female & & 45 & 28 & 17 & 62.2 & \\
\hline \multicolumn{7}{|c|}{ Smoking or not } \\
\hline Male & Smoking & 61 & 5 & 56 & 8.2 & \multirow{2}{*}{0.011} \\
\hline & No smoking & 32 & 9 & 23 & 28.1 & \\
\hline \multirow[t]{2}{*}{ Female } & Smoking & 6 & 1 & 5 & 16.7 & \multirow{2}{*}{0.030} \\
\hline & No smoking & 39 & 28 & 11 & 71.8 & \\
\hline \multicolumn{7}{|c|}{ Histological type } \\
\hline Ader & carcinoma & 121 & 41 & 80 & 33.9 & \multirow{2}{*}{0.039} \\
\hline squamol & cell carcinoma & 17 & 1 & 16 & 5.9 & \\
\hline
\end{tabular}

Table 4: Association between EGFR mutation, gender and histologic type in 138 NSCLC patients

\begin{tabular}{|c|c|c|c|c|c|c|}
\hline \multirow{2}{*}{ Gender } & \multicolumn{2}{|c|}{$\begin{array}{c}\text { Adenocarcinoma } \\
(n=121)\end{array}$} & \multirow{2}{*}{$\begin{array}{c}\text { Mutation rate } \\
(\%)\end{array}$} & \multicolumn{2}{|c|}{$\begin{array}{l}\text { Squamous cell carcinoma } \\
(n=17)\end{array}$} & \multirow{2}{*}{$\begin{array}{c}\text { Mutation rate } \\
(\%)\end{array}$} \\
\hline & $\begin{array}{l}\text { Mutant- } \\
\text { type }\end{array}$ & $\begin{array}{l}\text { Wild- } \\
\text { type }\end{array}$ & & Mutant-type & Wild-type & \\
\hline Male & 13 & 70 & 15.7 & 0 & 10 & 0 \\
\hline Female & 25 & 13 & 65.8 & 1 & 6 & 14.3 \\
\hline
\end{tabular}


EGFR mutations have been found more frequently in non-smoking East Asian women with adenocarcinoma with NSCLC $[17,18]$.

The ethnic and region differences in the incidence of EGFR mutations in NSCLC remain incompletely understood. In this study, we chose a population of Hubei patients to study the incidence rate of EGFR mutations. The overall mutation rate of EGFR gene was $30.43 \%$ in Hubei NSCLC patients, consistent with data reported for other East Asian populations [19]. The mutation rates of EGFR gene at exon 18, 19, 20, 21 were $0,13.8,0.7$ and $15.9 \%$, respectively. The mutation rate of EGFR gene was higher in female patients than that in males $(p<0.01)$, and higher in non-smoking patients than in smoking ones, this finding suggests that endogenous agents from female hormonederived mutagenic metabolites may play a role in EGFR mutagenesis.

Furthermore, it has been shown that females are more susceptible to environmental carcinogens because DNA mutations were more frequently found in never-smoking female than neversmoking male lung cancer patients [20]. But the mutation rate of EGFR gene had no correlation with age in NSCLC patients ( $p>0.05)$; EGFR mutation frequency in adenocarcinoma was higher than that in squamous cell carcinoma ( $p<$ 0.05 ), and the mutation rate of EGFR gene was also higher in female patients than that in males.

In our analysis, the frequency of EGFR mutations in patients who had never-smoking was $48.6 \%$ (35 of 72 patients). The frequency of EGFR mutations has been observed to vary from $26 \%$ to $68 \%$ based on how the mutational analysis was performed, geography and other clinical characteristics of the patients investigated [2123]. Shigematsu and Pham identified EGFR mutations in $51 \%$ of those who have never smoked (85 of 166, 34 of 67 patients), and so the results similar to ours $[19,24]$.

Clinical parameters and molecular characteristics are very useful to the therapy for lung cancer. The study demonstrate that a universally available and verifiable clinical characteristic can estimate the incidence of mutations in exons 18, 19, 20 and 21 of EGFR, and assist physicians in choosing appropriate therapy for each individual patient.

\section{Limitation of the study}

In this study, the sample size of participants was small; thus, the results may be biased.
Therefore, a study using a larger sample is required.

\section{CONCLUSION}

EGFR mutations in NSCLC patients are mainly found in exons 19 and 21, and the mutation rate of exon 21 is higher than that of exon 19, which is the one more commonly found in female, adenocarcinoma and non-smoking patients.

\section{DECLARATIONS}

\section{Acknowledgement}

The authors thank all the volunteers that participated in this study as well as Jing Yang, and Wuhan University, for expert assistance in analyzing the results of DNA sequencing.

\section{Conflict of Interest}

No conflict of interest associated with this work.

\section{Contribution of Authors}

The authors declare that this work was done by the authors named in this article and all liabilities pertaining to claims relating to the content of this article will be borne by them.

\section{REFERENCES}

1. Lin $\mathrm{CH}$, Yeh KT, Chang YS, Hsu NC, Chang JG. Rapid detection of epidermal growth factor receptor mutations with multiplex PCR and primer extension in lung cancer. J Biomed Sci 2010; 17: 37.

2. Pan Y, Zhang Y, Li Y, Hu H, Wang L, Li H, Wang R, Ye $T$, Luo $X$, Zhang $Y$, et al. Prevalence, clinicopathologic characteristics, and molecular associations of EGFR exon 20 insertion mutations in East Asian patients with lung adenocarcinoma. Ann Surg Oncol 2014; 21: S490496.

3. Lynch TJ, Bell DW, Sordella R, Gurubhagavatula $S$, Okimoto RA, Brannigan BW, Harris PL, Haserlat SM, Supko JG, Haluska FG, et al. Activating mutations in the epidermal growth factor receptor underlying responsiveness of non-small-cell lung cancer to gefitinib. N Engl J Med 2004; 350: 2129-2139.

4. Paez JG, Janne PA, Lee JC, Tracy S, Greulich H, Gabriel $S$, Herman P, Kaye FJ, Lindeman N, Boggon TJ, et al. EGFR mutations in lung cancer: correlation with clinical response to gefitinib therapy. Science 2004; 304: 14971500.

5. Pao W, Miller V, Zakowski M, Doherty J, Politi K, Sarkaria I, Singh B, Heelan R, Rusch V, Fulton L, et al. EGF receptor gene mutations are common in lung cancers from "never smokers" and are associated with

Trop J Pharm Res, August 2016; 15(8): 1640 
sensitivity of tumors to gefitinib and erlotinib. Proc Natl Acad Sci USA 2004; 101: 13306-13311.

6. Kobayashi S, Boggon TJ, Dayaram T, Janne PA, Kocher $O$, Meyerson $M$, Johnson BE, Eck MJ, Tenen DG, Halmos B. EGFR mutation and resistance of non-smallcell lung cancer to gefitinib. N Engl J Med 2005; 352:786-792.

7. Kosaka $T$, Yatabe $Y$, Endoh H, Kuwano H, Takahashi T, Mitsudomi T. Mutations of the epidermal growth factor receptor gene in lung cancer: biological and clinical implications. Cancer Res 2004; 64:8919-8923.

8. Pao W, Miller VA, Politi KA, Riely GJ, Somwar R, Zakowski MF, Kris MG, Varmus $H$. Acquired resistance of lung adenocarcinomas to gefitinib or erlotinib is associated with a second mutation in the EGFR kinase domain. PLoS Med 2005; 2:e73.

9. Han SW, Kim TY, Hwang PG, Jeong S, Kim J, Choi IS, Oh DY, Kim JH, Kim DW, Chung DH, et al. Predictive and prognostic impact of epidermal growth factor receptor mutation in non-small-cell lung cancer patients treated with gefitinib. J Clin Oncol 2005; 23:2493-2501.

10. Shigematsu H, Lin L, Takahashi T, Nomura M, Suzuki M, Wistuba II, Fong KM, Lee H, Toyooka S, Shimizu N, et al. Clinical and biological features associated with epidermal growth factor receptor gene mutations in lung cancers. J Natl Cancer Inst 2005; 97:339-346.

11. Chan IS, Ginsburg GS. Personalized medicine: progress and promise. Annu Rev Genomics Hum Genet 2011; 12:217-244

12. World Medical Association. World Medical Association Declaration of Helsinki: Ethical Principles for Medical Research Involving Human Subjects. Seoul: From the 59th World Medical Association Assembly, 2008. http://www.wma.net/en/30publications/10policies/b3/17c .pdf.

13. Maemondo $M$, Inoue $A$, Kobayashi $K$, Sugawara $S$, Oizumi S, Isobe H, Gemma A, Harada M, Yoshizawa H, Kinoshita l, et al. Gefitinib or chemotherapy for nonsmall-cell lung cancer with mutated EGFR. $N$ Engl J Med 2010; 362:2380-2388.

14. Rosell R, Carcereny E, Gervais $R$, Vergnenegre $A$, Massuti B, Felip E, Palmero R, Garcia-Gomez $R$, Pallares C, Sanchez JM, et al. Erlotinib versus standard chemotherapy as first-line treatment for European patients with advanced EGFR mutation-positive nonsmall-cell lung cancer (EURTAC): a multicentre, open- label, randomised phase 3 trial. Lancet Oncol 2012; 13:239-246.

15. Oda K, Matsuoka Y, Funahashi A, Kitano H. A comprehensive pathway map of epidermal growth factor receptor signaling. Mol Syst Biol 2005; 1:2005.

16. Krause DS, Van Etten RA: Tyrosine kinases as targets for cancer therapy. N Engl J Med 2005; 353:172-187.

17. Janne PA, Engelman JA, Johnson BE: Epidermal growth factor receptor mutations in non-small-cell lung cancer: implications for treatment and tumor biology. J Clin Oncol 2005; 23:3227-3234.

18. Sharma SV, Bell DW, Settleman J, Haber DA. Epidermal growth factor receptor mutations in lung cancer. Nat Rev Cancer 2007; 7:169-181.

19. Shigematsu H, Lin L, Takahashi T, Nomura M, Suzuki M, Wistuba II, Fong KM, Lee H, Toyooka S, Shimizu N, et al. Clinical and biological features associated with epidermal growth factor receptor gene mutations in lung cancers. J Natl Cancer Inst 2005; 97:339-346.

20. Yang SY, Yang TY, Li YJ, Chen KC, Liao KM, Hsu KH, Tsai CR, Chen CY, Hsu CP, Hsia JY, et al. EGFR exon 19 in-frame deletion and polymorphisms of DNA repair genes in never-smoking female lung adenocarcinoma patients. Int J Cancer 2013; 132:449-458.

21. Kosaka T, Yatabe Y, Endoh H, Kuwano H, Takahashi T, Mitsudomi T. Mutations of the epidermal growth factor receptor gene in lung cancer: Biological and clinical implications. Cancer Res 2004; 64:8919-8923.

22. Cortes-Funes $H$, Gomez $C$, Rosell $R$, Valero $P$, GarciaGiron C, Velasco A, Izquierdo A, Diz P, Camps C, Castellanos $D$, et al. Epidermal growth factor receptor activating mutations in Spanish gefitinib-treated nonsmall-cell lung cancer patients. Ann Oncol 2005; 16:1081-1086.

23. Han SW, Kim TY, Hwang PG, Jeong S, Kim J, Choi IS, Oh DY, Kim JH, Kim DW, Chung DH, et al. Predictive and prognostic impact of epidermal growth factor receptor mutation in non-small-cell lung cancer patients treated with gefitinib. J Clin Oncol 2005; 23:2493-2501.

24. Pham D, Kris MG, Riely GJ, Sarkaria IS, McDonough T, Chuai S, Venkatraman ES, Miller VA, Ladanyi M, Pao $W$, et al. Use of cigarette-smoking history to estimate the likelihood of mutations in epidermal growth factor receptor gene exons 19 and 21 in lung adenocarcinomas. J Clin Oncol 2006; 24:1700-1704. 